\author{
반추위 보호 Choline이 In vitro 반추위 발효특성과 착유우의 \\ 유생산 및 유조성분에 미치는 영향 \\ 박병기* · 김병완** . 장현용** · 신종서**
}

\title{
Effects of Rumen Protected Choline on In vitro Ruminal Fermentation and Milk Production and Its Composition in Lactating Cows
}

\author{
Byung Ki Park*, Byong Wan Kim**, Hyun Yong Jang** and Jong Suh Shin**
}

\begin{abstract}
This study was conducted to evaluate the effects of rumen protected choline on in vitro ruminal fermentation and milk production and its composition in Holstein cows. Experiments were done with three treatment groups, basal diet without any supplement (T1), basal diet+23g/d of mixture of choline and wheat shorts (T2) and basal diet $+25.56 \mathrm{~g} / \mathrm{d}$ of rumen protected choline (T3). The in vitro ruminal $\mathrm{pH}$ and ammonia concentrations were similar for three treatments during all incubation periods except for the in vitro ruminal $\mathrm{pH}$ on $3 \mathrm{hr}$ incubation and ammonia concentrations on $9 \mathrm{hr}$ incubation. No significant difference was found in the concentrations of acetate and total-VFA. The propionate and butyrate concentrations were not affected by the rumen protected choline except on $6 \mathrm{hr}$ incubation on which the propionate and butyrate concentrations were intermediate $(8.98 \mathrm{mg} / \mathrm{dl})$ and least $(3.22 \mathrm{mg} / \mathrm{dl})$, respectively. Higher milk yield and milk fat and lactose were resulted in the rumen protected choline. However, the rumen protected choline did not affect the milk protein, solids not fat, total solids, MUN, somatic cell count. It is concluded that the rumen protected choline can be effective materials to improve the milk production, milk fat and lactose without little change on in vitro ruminal fermentation.
\end{abstract}

(Key words : Rumen protected choline, In vitro ruminal fermentation, Milk production, Holstein cows)

$$
\text { I. 서 론 }
$$

가축의 사료에 존재하는 choline은 주로 인지 질의 형태로 순수 비타민은 아니지만 비타민 $\mathrm{B}$ 군의 일종으로 분류되고 있다 (McDowell, 1989). Choline은 뇌 및 신경 자극 신호 전달에 중요한 acetylcholine의 형성 및 세포의 구성과
유지에 필수적인 성분이며 (Hartwell 등, 2000; $\mathrm{NRC}, 2000)$, 세포막의 보전 및 지질의 소화와 흡수에 있어서도 중요한 역할을 하는 것으로 보고된 바 있다 (Bindel 등, 2000).

사료내 choline 혹은 반추위 보호처리를 하지 않은 choline의 공급은 반추위에서 대부분이 분 해되는데 (Atkins 등, 1988; Sharma와 Erdman,

* 농촌진흥청 축산과학원 (National Institute of Animal Science, RDA, Korea)

** 강원대학교 동물생명과학대학 (College of Animal Life Science, Kangwon National University, Korea)

Corresponding author: Jong Suh Shin, Division of Animal Resource Science, Kangwon National University, Chuncheon 200-701, Korea.

Tel: +82-33-250-8628, Fax: +82-33-244-2532, E-mail: jsshin@kangwon.ac.kr 
1988), 반추위 미생물들은 free choline을 trimethylamine이라는 중간 대사산물을 거쳐 methane으로 전환시키며 (Neill 등, 1978), free choline의 일부는 프로토조아의 phosphatidylcholine 합성을 위해 이용된다 (Bygrave와 Dawson, 1976). 따라서 사료내 choline의 $1 \%$ 이 하만이 소장에 도달하게 되므로(Van Horn과 Wilcox, 1999) 반추위 보호 처리를 하지 않은 choline의 공급 효과는 없는 것으로 보고된 바 있다 (Erdman, 1992).

Swingle과 Dyer (1970)는 choline의 공급으로 휘발성지방산 생성량이 증가되었다고 보고한 반면에 Erdman (1984)은 착유우에서 choline의 공급이 휘발성지방산 농도에 미치는 영향은 없 었다고 보고한 바 있다. 또한 Atkins 등 (1988) 은 choline 공급시 반추위 $\mathrm{pH}$ 와 acetate 농도는 증가되는 경향을 보인 반면에 propionate 농도 에 대한 choline의 영향은 없었다고 보고하여 반추위 발효에 대한 choline의 영향에 관한 연 구결과는 상대적으로 부족할 뿐만 아니라 일관 성도 결여되어 있다.

한편, 대부분의 가축에서 choline 결핍의 주 요한 증상은 지방간 증후군인데 (NRC, 2001; Van Horn과 Wilcox, 1999), 특히, 지방간 증후 군은 상당수 $(30 \%$ 이상 $)$ 의 고능력우들이 겪고 있는 대사성 질병이다 (Reid와 Collins, 1980). 비록 착유우에서 아직까지 choline의 요구량이 확실히 정착되지는 못했지만, 4 위 혹은 소장을 통한 직접적인 choline 주입실험 (Erdman과 Sharma, 1991; Sharma와 Erdman, 1989)에서 choline은 착유우에서 제한 영양소라는 사실이 증명되어 왔다.

일반적으로 착유우에서 분만 전후 및 비유초 기 동안 생리적으로 사료섭취량이 감소되고 간 에 지질이 축적되며 (Bertics 등, 1992), 에너지 요구량을 충족시키기 위해 지방조직으로부터 많은 양의 지방산이 동원되어 혈중 유리지방산 (NEFA) 농도가 증가하게 된다 (Bell, 1995). 반 추가축의 경우 유리지방산은 간에서 very low density lipoproteins (VLDL)으로 산화 및 배출되 는데 (Emery 등, 1992), 반추가축의 간에서 $\mathrm{VLDL}$ 로 지방산의 산화 및 배출 능력은 낮기 때문에 (Grummer, 1993) 유리지방산의 과도한 축적은 지방간의 발달을 초래하게 된다. 그러 나 choline은 간으로부터 VLDL 합성 및 에스 테르화된 지질의 분비 증가(Piepenbrink와 Overton, 2003)와 gluconeogenesis의 활성화(CadornigaValino 등, 1997), 즉 choline은 지질의 수송 촉 진을 통해 간에서 지질의 비정상적인 축적을 방지하거나 지방산의 이용성을 증진시키기 때 문에 간의 지방대사에서 필수적인 역할을 한다 (Bryant 등, 1999).

착유우에서 4 위를 통한 choline의 직접적인 공급 혹은 반추위 보호 choline의 급여는 산유 량 (Pinotti 등, 2001), 유지방 (Sharma와 Erdman, 1989) 및 일부 지방산 (Piepenbrink와 Overton, 2003) 함량을 증가시키는 것으로 보고된 바 있 으나, 보호 choline의 공급에 따른 착유우의 생 산반응의 결과는 일관성이 결여되어 있는 것으 로 보고된 바 있다 (Atkins 등, 1988).

따라서 본 연구에서는 반추위 보호 choline의 급여가 in vitro 반추위 발효특성과 착유우의 유생산성에 미치는 영향을 검토하기 위해 수행 되었다.

\section{․ 재료 및 방법}

\section{1. 공시동물 및 사양관리}

In vitro 반추위 발효특성 조사를 위한 시험 에서는 반추위 cannula가 장착된 한우 2두 (400 및 $420 \mathrm{~kg}$ )를 공시하여 실시하였는데, 각 실험 은 14 일간 사료 적응기간을 거친 후 마지막 15 일에 위액을 채취하여 본 실험을 수행하였으 며, 동일한 실험을 3회 반복하여 실시하였다. 사료급여는 일일 2회 (오전 9:00 및 오후 6:00) 공시축 체중의 $1.5 \% / \mathrm{DM}$ 로 급여하였으며, 급여 사료는 시판 배합사료와 호밀 건초를 이용하였 
고 (Table 1), 시험사료의 조농비율은 50:50으로 하였다. 물과 미네랄 블록은 항상 이용가능 하 도록 하였다.

사양시험은 홀스타인 착유우 (평균 산차 : 2.98) 45두를 공시하여 30일씩 3회 반복하여 90일간 동일 실험을 실시하였다. 시험사료는 $\mathrm{TMR}$ 을 자유채식 시켰으며, 착유는 일일 2회 (오전 7:00 및 오후 7:00) 실시하였다. TMR의 배합비와 영 양수준은 Table 2와 같다.

\section{2. 반추위 보호 choline의 제조}

본 시험에서는 보호 choline의 제조를 위해 우선 choline chloride (순도 99\%)를 증류수에 녹여 70\% choline chloride 수용액을 제조하였 다. 보호 choline의 제조를 위해 사용된 외부 코팅물질은 gelatin, arabic gum 및 ethylcellulose 이었으며, 코팅 비율은 $10 \%$ 였다(1차 코팅 $5 \%$, 2차 코팅 5\%). 우선 gelatin powder 및 arabic gum powder $25 \mathrm{~g}$ 을 각각 $125 \mathrm{ml}$ 의 증류수에 완 전히 녹인 후 합쳐서 3 시간 동안 교반하여 1차 코팅액을 제조하였다. 다음으로 ethylcellulose powder $50 \mathrm{~g}$ 을 $700 \mathrm{ml}$ 의 아세톤과 $300 \mathrm{ml}$ 의 ethanol 용액에 충분히 녹인 후 polyethylene glycol compound $10 \mathrm{~g}$ 과 talc $2.5 \mathrm{~g}$ 을 첨가하여 6 시간 동안 충분히 교반하여 2차 코팅액을 제 조하였다.

보호 choline의 제조를 위해 fruidized bed coating system을 응용한 top spray 방식의 코팅 기를 이용하였다. 우선 코팅기 $\left(50^{\circ} \mathrm{C}\right)$ 에 부형제
(말분)를 넣고 $70 \%$ choline chloride 수용액을 분사하여 부형제에 choline을 흡착시킨 후 $50^{\circ} \mathrm{C}$ 의 송풍식 drying oven에서 건조과정을 거친 후 choline 함량 25\%의 혼합물 $(70 \%$ choline chloride 수용액 : 부형제 $=35.7 \%: 64.3 \%$ )을 제조 하였다. 건조된 혼합물은 입자의 균일성을 위 해 sieve No. 20을 통과한 시료만을 1 및 2차 코팅에 이용하였다. 건조가 완료된 시료를 코 팅기에 넣고 1 차 코팅액으로 코팅을 실시한 후 $50{ }^{\circ} \mathrm{C}$ 의 송풍식 drying oven에서 48시간 동안 건조를 실시하였다. 건조가 완료된 시료를 다 시 코팅기에 넣고 2차 코팅액으로 코팅을 실시 한 후 $50{ }^{\circ} \mathrm{C}$ 의 송풍식 drying oven에서 48시간 동안 건조를 실시하였다. 보호 choline의 제조 를 위한 coating 조건은 다음과 같다. Atomizing air spray gun (Seiki, Japan): 1.4 1.6 bar, nozzle size: $0.8 \mathrm{~mm}$, spray rate: $10 \mathrm{ml} / \mathrm{min}$ 및 inlet temperature: $50 \pm 3^{\circ} \mathrm{C}$.

\section{3. 시험구 배치}

In vitro 소화시험은 2 대의 DAISY ${ }^{\Pi}$ incubator (Ankom, USA)를 이용하여 실시하였는데, 시험 기간 동안 incubator의 온도는 항상 $39.5 \pm 0.5^{\circ} \mathrm{C}$ 로 유지하였다. 시험구 처리는 6개의 jar(처리 당 2반복)에 건조 후 입자크기를 $1 \mathrm{~mm}$ 로 분쇄 한 배합사료와 호밀 건초를 각각 $4 \mathrm{~g}$ 씩과 여기 에 dextrose와 xylose를 각각 $2 \mathrm{~g}$ 씩 첨가한 대조 구 (T1), 대조구 사료 + choline과 부형제의 혼합 물 $23 \mathrm{~g} /$ 일 첨가구 $(\mathrm{T} 2)$ 및 대조구 사료 + 보호

Table 1. Chemical composition of experimental diets for in vitro trial(DM basis)

\begin{tabular}{lcc}
\hline Items & Concentrate diet & \multicolumn{1}{c}{ Rye hay } \\
\hline \hline Dry matter (\%) & $91.58 \pm 0.08$ & $91.87 \pm 0.24$ \\
Crude protein (\%) & $15.12 \pm 0.75$ & $9.30 \pm 0.29$ \\
Ether extract (\%) & $2.57 \pm 0.04$ & $1.94 \pm 0.07$ \\
Crude ash (\%) & $8.34 \pm 0.15$ & $6.05 \pm 0.58$ \\
$\mathrm{NDF}^{1}(\%)$ & $34.52 \pm 1.59$ & $72.08 \pm 0.20$ \\
$\mathrm{ADF}^{2}(\%)$ & $14.23 \pm 0.48$ & $45.69 \pm 0.59$ \\
\hline
\end{tabular}

$\mathrm{NDF}^{1}$ : neutral detergent fiber; $\mathrm{ADF}^{2}$ : acid detergent fiber. 
Table 2. Formula and chemical composition of total mixed ration

\begin{tabular}{lc}
\hline Items & Percentage $(\%)$ \\
\hline \hline Formula composition & \\
Formula feed & 39.29 \\
Beet pulp & 7.86 \\
Timothy & 15.72 \\
Alfalfa & 3.93 \\
Tall fescue & 15.72 \\
Wet brewer’s grain & 15.72 \\
Vitamin mix & 1.18 \\
Sodium bicarbonate & 0.59 \\
\hline Chemical composition(DM basis) \\
Crude protein \\
Ether extract & $18.92 \pm 0.46$ \\
Crude ash & $3.87 \pm 0.04$ \\
NDF & $6.29 \pm 0.58$ \\
ADF & $43.52 \pm 1.43$ \\
\hline
\end{tabular}

choline $25.56 \mathrm{~g} /$ 일 첨가구 (T3)의 3처리로 구분 하여 실시하였다 (Table 3). 한편, 보호 choline 제조과정에서 사용된 부형제의 영향을 검토하 기 위한 $\mathrm{T} 2$ 구의 choline과 부형제의 혼합물은 70\% choline chloride 수용액을 부형제 (말분)에 분사하여 choline을 흡착시켜 건조시킨 후 1 및 2 차 코팅을 하지 않은 혼합물을 의미한다.

사양시험을 위한 시험구 처리는 $\mathrm{TMR}$ 만을 급여하는 대조구 (T1), TMR + choline과 부형제 의 혼합물 $23 \mathrm{~g} /$ 일 첨가구 (T2) 및 $\mathrm{TMR}+$ 보호 choline $25.56 \mathrm{~g}$ /일 첨가구(T3)의 3처리로 하였다.

\section{4. 실험 방법 및 조사항목}

반추위액의 채취는 반추위에 cannula가 장착 된 한우 암소에서 오전사료 급여 전에 채취하 여 4겹의 cheese cloth로 여과한 후 미리 예열 된 $39^{\circ} \mathrm{C}$ 보온병에 담고, $\mathrm{O}_{2}$ free- $\mathrm{CO}_{2}$ gas를 30 초간 주입하여 보온병내의 공기를 제거한 후 30 분내로 실험실로 운반하여 실험에 이용하였다.

In vitro 배양액은 반추위액 $400 \mathrm{ml}$ 를 미리 제조한 buffer solution (A 및 B) 1,600 ml와 첨
Table 3. Composition of buffer solutions for in vitro trial

\begin{tabular}{|c|c|c|}
\hline Components & Amount & Unit \\
\hline \multicolumn{3}{|l|}{ Buffer solution A: } \\
\hline $\mathrm{KH}_{2} \mathrm{PO}_{4}$ & 10.0 & g \\
\hline $\mathrm{MgSO}_{4} \cdot 7 \mathrm{H}_{2} \mathrm{O}$ & 0.5 & g \\
\hline $\mathrm{NaCl}$ & 0.5 & g \\
\hline $\mathrm{CaCl}_{2} \cdot 2 \mathrm{H}_{2} \mathrm{O}$ & 0.1 & g \\
\hline Urea & 0.5 & g \\
\hline Distilled water & 1000 & $\mathrm{ml}$ \\
\hline \multicolumn{3}{|l|}{ Buffer solution B: } \\
\hline $\mathrm{Na}_{2} \mathrm{CO}_{3}$ & 15.0 & $\mathrm{~g}$ \\
\hline $\mathrm{NaS} \cdot 9 \mathrm{H}_{2} \mathrm{O}$ & 1.0 & g \\
\hline Distilled water & 1000 & $\mathrm{ml}$ \\
\hline
\end{tabular}

가하여 제조하였는데, buffer solution은 Table 3 의 비율로 buffer solution $\mathrm{A}$ 와 $\mathrm{B}$ 로 구분하여 제조한 후 buffer solution A 1,330 ml와 buffer solution B $266 \mathrm{ml}$ 를 동시에 배양 jar에 넣어 혼 합한 후 $\mathrm{pH}$ 가 6.8이 되도록 조정하였으며, 39 ${ }^{\circ} \mathrm{C}$ 까지 예열시켰다. Buffer solution에 반추위액 의 첨가 즉시 $\mathrm{O}_{2}$ free- $\mathrm{CO}_{2}$ gas를 30초간 주입하 여 배양 jar내의 공기를 배제하였으며, 그 후 $39^{\circ} \mathrm{C}$ 에서 1 시간 동안 안정시킨 후 본 시험에 이용하였다.

In vitro 배양 $0,3,6,9,12$ 및 24시간 별로 각각 배양액을 채취하는 즉시 $\mathrm{pH}$ meter (Corning 445, USA)로 $\mathrm{pH}$ 를 측정하고, $4^{\circ} \mathrm{C}$ 에서 $3,000 \mathrm{rpm}$ 으로 15 분간 원심 분리한 후 상층액 을 취하여 ammonia 농도 측정에 이용하였다. Ammonia 농도는 자동분석기 (Quikchem 8000, USA)를 이용하여 측정하였다.

한편, in vitro 배양액의 휘발성지방산의 농도 를 분석하기 위해 $0,3,6,9,12$ 및 24시간대별 로 $5 \mathrm{ml}$ 의 배양액을 채취한 후 $20 \%$ 의 $\mathrm{HPO}_{3} 1$ $\mathrm{ml}$ 및 포화 $\mathrm{HgCl}_{2} \quad 0.5 \mathrm{ml}$ 를 첨가하고 $4^{\circ} \mathrm{C}$ 에서 $3,000 \mathrm{rpm}$ 으로 15 분간 원심 분리하여 상층액을 취한 후 gas chromatography (Shimadzu Model GC-17A Ver. 3, Japan)을 이용하여 휘발성지방 산 농도를 측정하였다. 
산유량은 매 착유시에 조사를 하였으며, 우 유 시료는 30 일 간격으로 2일 연속하여 오전 및 오후 착유시에 채취하여 3 개의 시료로 구분 하였다. 첫 번째 시료는 유지방, 유단백질, 유 당, 무지고형분 (solid not fat; SNF) 및 총고형 물 함량 분석에 이용하였고, 두 번째 시료는 milk urea nitrogen (MUN) 및 체세포수 (somatic cell count; SCC)의 분석에 이용하였으며, 세 번 째 시료는 지방산 분석을 위해 $-45^{\circ} \mathrm{C}$ 에 냉동 보관하였다.

유지방, 유단백질, 유당, 무지고형분 및 총고 형물 함량은 Milkoscan (Foss Technology, Denmark)을 이용하여 분석하였으며, 우유의 지방 산 분석은 Folch 등 (1957)의 방법에 준하여 chloroform-methanol (2:1)을 이용한 지질을 추출 한 후 Sukhija와 Palmquist (1988)의 방법에 준 하여 gas chromatography (Shimadzu Model GC$17 \mathrm{~A}$ Ver. 3, Japan)를 이용하여 분석하였다.

\section{5. 통계처리}

본 실험에서 얻어진 결과들은 SAS package (1999)를 이용하여 분산분석 및 Duncan의 multiple range test로 처리구간의 유의성 $(\mathrm{p}<$ 0.05)을 검증하였다.

\section{III. 결과 및 고찰}

반추위 보호 choline의 첨가가 in vitro 배양 액의 $\mathrm{pH}$ 에 미치는 영향은 3시간을 제외한 전 배양시간에서 없었으며 (Table 4), in vitro 배양 24시간 동안의 평균 $\mathrm{pH}$ 에 대한 보호 choline 첨가의 영향도 없었다. 또한 in vitro 배양액의 ammonia 농도에 대한 보호 choline의 영향도 배양 9 시간을 제외한 전 배양시간에서 없었으 며, 보호 choline의 첨가에 따른 in vitro 배양 24시간의 평균 ammonia 농도의 처리간 차이도

Table 4. Effects of rumen protected choline on the in vitro ruminal $\mathrm{pH}$ and ammonia

\begin{tabular}{lccccc}
\hline Items & Times (hr) & $\mathrm{T}^{1}$ & $\mathrm{~T}^{2}$ & $\mathrm{~T}^{3}$ & $\mathrm{SEM}^{4}$ \\
\hline \hline & 0 & 6.81 & 6.82 & 6.81 & 0.01 \\
& 3 & $6.32^{\mathrm{b}}$ & $6.40^{\mathrm{a}}$ & $6.45^{\mathrm{a}}$ & 0.02 \\
$\mathrm{pH}$ & 6 & 6.32 & 6.31 & 0.02 \\
& 9 & 6.28 & 6.24 & 6.29 & 0.02 \\
& 12 & 6.31 & 6.22 & 6.26 & 0.02 \\
& 24 & 6.18 & 6.05 & 6.13 & 0.02 \\
& Mean & 6.37 & 6.34 & 6.38 & 0.05 \\
\hline & 0 & 15.94 & 18.02 & 17.01 & 0.51 \\
Ammonia(mg/dl) & 20.27 & 18.26 & 20.91 & 0.76 \\
& 12 & 19.42 & 19.50 & 19.06 & 0.52 \\
& 12 & 18.37 & 18.11 & 19.81 & 0.54 \\
& $18.42^{\mathrm{b}}$ & $18.42^{\mathrm{b}}$ & $22.71^{\mathrm{a}}$ & 0.79 \\
& 26.41 & 22.63 & 25.17 & 0.68 \\
\hline
\end{tabular}

a,b,c Means with different superscripts in the same row differ significantly $(\mathrm{p}<0.05)$.

$\mathrm{T}^{1}{ }^{1}$ : control diet without any supplement; $\mathrm{T}^{2}$ : control diet $+23 \mathrm{~g} / \mathrm{d}$ of mixture of choline and wheat shorts; $\mathrm{T3}^{3}$ : control diet $+25.56 \mathrm{~g} / \mathrm{d}$ of rumen protected choline; $\mathrm{SEM}^{4}$ : standard error of the mean. 
없었다.

본 시험에서 보호 choline의 첨가가 in vitro 배양액에 대한 영향은 적었는데, 이와 같은 결 과는 choline 첨가가 in vitro 배양액의 $\mathrm{pH}$ (Atkins 등, 1988) 및 ammonia 농도 (Sharma와 Erdman, 1989)에 미치는 영향이 적었다는 이전 의 연구결과와 유사한 경향을 보인 것으로 판 단된다. 또한 본 시험에서 부형제의 영향을 조 사하기 위해 시험구로 설정했던 보호 처리를 하지 않은 choline과 부형제의 혼합물 첨가구
(T2)의 경우에도 대조구 (T1) 및 보호 choline 첨가구(T3)와 대부분의 시간대에서 in vitro 배 양액의 $\mathrm{pH}$ 및 ammonia 농도의 차이를 보이지 않아 choline은 보호처리의 여부에 관계없이 반 추위 $\mathrm{pH}$ 및 ammonia 농도에 미치는 영향은 적 은 것으로 판단된다.

보호 choline의 첨가가 in vitro 배양액의 acetate 및 total-VFA 농도에 미치는 영향은 없 었으며 (Table 5), in vitro 배양액의 propionate 및 butyrate 농도의 경우 배양 6시간을 제외한

Table 5. Effects of rumen protected choline on the in vitro ruminal volatile fatty acid(VFA)

\begin{tabular}{|c|c|c|c|c|c|}
\hline Items & Time(hr) & $\mathrm{T} 1$ & $\mathrm{~T} 2$ & T3 & SEM \\
\hline \multirow{7}{*}{ Acetate (mg/dl) } & 0 & 11.21 & 8.05 & 10.78 & 0.47 \\
\hline & 3 & 19.39 & 15.10 & 18.06 & 0.83 \\
\hline & 6 & 23.24 & 27.77 & 26.23 & 1.58 \\
\hline & 9 & 26.89 & 21.95 & 26.52 & 1.18 \\
\hline & 12 & 29.99 & 24.09 & 28.18 & 0.94 \\
\hline & 24 & 31.24 & 33.87 & 29.67 & 1.70 \\
\hline & Mean & 23.66 & 21.81 & 23.24 & 1.78 \\
\hline \multirow{7}{*}{ Propionate (mg/dl) } & 0 & 2.40 & 2.24 & 2.42 & 0.11 \\
\hline & 3 & 5.64 & 5.25 & 5.75 & 0.13 \\
\hline & 6 & $7.13^{\mathrm{b}}$ & $11.10^{\mathrm{a}}$ & $8.98^{\mathrm{ab}}$ & 0.60 \\
\hline & 9 & 7.72 & 7.48 & $8.06^{\mathrm{a}}$ & 0.39 \\
\hline & 12 & 8.49 & 8.00 & 9.26 & 0.30 \\
\hline & 24 & 11.26 & 10.09 & 10.51 & 0.43 \\
\hline & Mean & 7.11 & 7.36 & 7.33 & 0.57 \\
\hline \multirow{7}{*}{ Butyrate (mg/dl) } & 0 & 1.59 & 1.10 & 1.43 & 0.08 \\
\hline & 3 & 2.23 & 2.19 & 2.27 & 0.09 \\
\hline & 6 & $3.55^{\mathrm{ab}}$ & $4.52^{\mathrm{a}}$ & $3.22^{\mathrm{b}}$ & 0.25 \\
\hline & 9 & 4.16 & 4.62 & 4.13 & 0.15 \\
\hline & 12 & 4.92 & 5.21 & $4.85^{\mathrm{b}}$ & 0.19 \\
\hline & 24 & 2.60 & 2.53 & 4.28 & 0.40 \\
\hline & Mean & 3.17 & 3.36 & 3.13 & 0.24 \\
\hline \multirow{7}{*}{ Total-VFA (mg/dl) } & 0 & 15.69 & 11.74 & 15.11 & 0.63 \\
\hline & 3 & 28.07 & 23.17 & 26.79 & 0.97 \\
\hline & 6 & 34.67 & 44.24 & 39.19 & 2.39 \\
\hline & 9 & 39.54 & 34.87 & 40.07 & 1.75 \\
\hline & 12 & 44.30 & 38.22 & 42.15 & 1.30 \\
\hline & 24 & 46.28 & 47.67 & 43.33 & 2.16 \\
\hline & Mean & 34.76 & 33.32 & 34.44 & 2.53 \\
\hline
\end{tabular}

$\overline{\text { a,b,c }}$ Means with different superscripts in the same row differ significantly $(\mathrm{p}<0.05)$. 
전 배양시간에서 보호 choline 첨가의 영향은 없었다.

본 시험의 결과에서 보호 choline의 첨가가 in vitro 배양액의 개별 및 총 휘발성지방산 농 도에 미치는 영향은 적은 것으로 판단되는데, choline의 첨가가 반추위 혹은 in vitro 반추위 액의 휘발성지방산 농도에 미치는 영향이 적었 다는 이전의 연구결과들 (Sharma와 Erdman, 1989; Erdman, 1984)과 유사한 경향을 보여 보 호 choline의 첨가가 휘발성지방산 농도 변화에 미치는 영향은 적은 것으로 사료된다. 다만 본 시험에서는 보호 처리를 거치지 않은 choline과 부형제의 혼합물 첨가구 (T2)에서 배양 6시간에 일시적으로 propionate 및 butyrate 농도가 증가 했던 결과는 choline의 영향이라기 보다는 부형 제로 이용된 말분의 탄수화물 성분에 대한 미 생물 분해에 원인이 있는 것으로 판단된다.

따라서 보호 choline의 첨가가 $\mathrm{pH}$, ammonia 및 휘발성지방산 농도 즉, 전반적인 in vitro 발 효특성에 미치는 영향은 없었으며, choline의 흡착을 위해 사용했던 부형제도 in vitro 발효 특성에 별다른 영향을 미치지 않는 것으로 나 타나 본 시험에서 제조된 보호 choline은 별다 른 문제없이 반추가축에 대한 적용이 가능한
것으로 판단된다.

보호 choline의 급여로 착유우의 산유량은 $12.7 \%$ (25.02 vs $28.21 \mathrm{~kg} /$ 일) 증가되었으며( $\mathrm{p}<$ 0.05 , Table 6), 유지방 (3.77 vs $4.12 \%$ ) 및 유당 (4.44 vs 4.73\%) 함량도 보호 choline의 급여로 증가되는 결과를 보였다 $(\mathrm{p}<0.05)$. 보호 choline 의 급여가 착유우의 유단백질, 무지고형분, 총 고형물, MUN 및 체세포수에 미치는 영향은 없 었다. 또한 우유 중 지방산 함량에 대한 보호 choline의 영향도 나타나지 않았다 (Table 7).

본 시험에서 착유우의 산유량이 증가되었던 결과는 보호 choline의 급여 혹은 4 위를 통한 직접적인 choline 공급시 착유우의 산유량이 증 가되었다는 이전의 연구결과들 (Piepenbrink와 Overton, 2003; Pinotti 등, 2001; Sharma와 Erdman, 1987)과 유사한 경향을 보였다. Kerri 등 (1998)은 보호 choline의 첨가량 (0 75 g/일)을 달리한 실험에서 본 시험과 첨가량이 거의 동 일한 일일 $25 \mathrm{~g}$ 급여구에서 일일 50 및 $75 \mathrm{~g}$ 급 여구에 비해 유량 증가가 많은 경향을 보였다 고 보고한 바도 있다. 또한 choline과 methionine의 대사과정은 상당히 유사하며 체내로 흡수된 methionine이 많게는 28\% 정도가 choline 합성에 이용되는데 (Emmanuel와 Kennelly, 1984),

Table 6. Effects of rumen protected choline on milk properties in Holstein cows

\begin{tabular}{lcccc}
\hline Items & $\mathrm{T}^{1}$ & $\mathrm{~T}^{2}$ & $\mathrm{~T}^{3}$ & $\mathrm{SEM}^{4}$ \\
\hline \hline Yield (kg/d) & $25.02^{\mathrm{b}}$ & $26.07^{\mathrm{ab}}$ & $28.21^{\mathrm{a}}$ & 0.61 \\
Fat (\%) & $3.77^{\mathrm{b}}$ & $3.91^{\mathrm{b}}$ & $4.12^{\mathrm{a}}$ & 0.04 \\
Protein (\%) & 3.26 & 3.29 & 3.31 & 0.02 \\
Lactose (\%) & $4.44^{\mathrm{c}}$ & $4.53^{\mathrm{b}}$ & $4.73^{\mathrm{a}}$ & 0.01 \\
$\mathrm{SNF}^{5}(\%)$ & 8.49 & 8.59 & 8.60 & 0.02 \\
Total solid (\%) $_{\text {MUN }}^{6}(\mathrm{mg} / \mathrm{dl})$ & 12.71 & 12.51 & 12.79 & 0.18 \\
$\operatorname{SCC}^{7}\left(\times 10^{4}\right)$ & 13.74 & 13.28 & 13.43 & 0.30 \\
\hline
\end{tabular}

a,b,c Means with different superscripts in the same row differ significantly $(\mathrm{p}<0.05)$.

$\mathrm{T}^{1}{ }^{1}$ : TMR without any supplement; $\mathrm{T}^{2}$ : $\mathrm{TMR}+23 \mathrm{~g} / \mathrm{d}$ of mixture of choline and wheat shorts; $\mathrm{T}^{3}$ : $\mathrm{TMR}+25.56$ $\mathrm{g} / \mathrm{d}$ of rumen protected choline; $\mathrm{SEM}^{4}$ : standard error of the mean; $\mathrm{SNF}^{5}$ : solid not fat; $\mathrm{MUN}^{6}$ : milk urea nitrogen; $\mathrm{SCC}^{7}$ : somatic cell count. 
Table 7. Effects of rumen protected choline on composition of milk fatty acids in Holstein cows

\begin{tabular}{lrrrl}
\hline Items & T1 & T2 & T3 & SEM \\
\hline \hline C14:0 (\%) & 13.97 & 14.83 & 15.29 & 0.32 \\
C16:0 (\%) & 40.05 & 41.01 & 40.24 & 0.46 \\
C18:0 (\%) & 11.98 & 10.97 & 11.48 & 0.26 \\
C18:2n6 (\%) & 2.39 & 2.29 & 2.23 & 0.07 \\
C18:1n9 (\%) & 29.91 & 28.77 & 28.75 & 0.51 \\
C16:1n7 (\%) & 1.69 & 2.13 & 2.01 & 0.22 \\
SFA $^{1}(\%)$ & 66.01 & 66.81 & 67.01 & 0.56 \\
USFA $^{2}(\%)$ & 33.99 & 33.19 & 32.99 & 0.56 \\
\hline
\end{tabular}

$\mathrm{SFA}^{1}$ : total content of saturated fatty acids;

USFA $^{2}$ : total content of unsaturated fatty acids.

choline을 추가적으로 공급하게 되면 choline 합 성을 위해 사용되는 methionine이 감소되어 다 른 체대대사 과정에 이용될 수 있다. 즉 단백 질 합성 증가, 유량 증가 및 $\mathrm{VLDL}$ 합성의 증 가 (Auboiron 등, 1995)에 따른 비유초기 혈장 내 케톤체의 감소(Durand 등, 1992) 등과 같은 methionine의 이용성 증가도 산유량 증가의 원 인 중의 하나인 것으로 추정된다.

본 시험에서 보호 choline의 급여로 착유우의 유지방 함량이 개선된 결과도 보호 choline 혹 은 4위를 통해 choline의 직접적인 공급시 착유 우의 유지방 함량이 증가되었다는 이전의 연구 결과들 (Erdman과 Sharma, 1991, Atkins 등, 1988)과 유사한 경향을 보인 것으로 사료된다. 보호 choline의 급여로 유지방 함량이 증가되는 원인은 체내에서 choline의 생리적인 기능과 관 련이 있는데, choline (phosphatidylcholine)이 간 으로부터 혈액을 통한 지질 (지방산)의 수송에 관여하여 유선조직에서 유지방 합성을 위한 지 방산 (Emery 등, 1992) 및 중성지방 (Piepenbrink 와 Overton, 2003)의 공급 증가 및 이용성 증가 에 원인이 있는 것으로 추정된다.

한편 본 시험에서 보호 choline의 급여로 유 당이 증가되는 결과를 보였는데, choline은 gluconeogenesis를 활성화 시켜 (Piepenbrink와
Overton, 2003) 혈중 glucose 농도에 영향을 미 치므로 (Hartwell 등, 2000; Cadorniga-Valino 등, 1997), 본 시험에서도 유당 함량이 증가되었던 원인은 보호 choline의 급여로 인해 유선조직으 로 유당 합성을 위한 에너지 및 glucose 공급 증가 때문인 것으로 판단된다.

본 시험에서 보호 choline의 급여가 착유우의 유단백질 함량 변화에 미치는 영향은 없었는 데, 이와 같은 결과는 보호 choline이 유단백질 함량 변화에 미치는 영향은 없었다는 이전의 연구결과들 (Piepenbrink와 Overton, 2003; Atkins 등, 1988)과는 유사한 반면에 보호 choline의 급여로 유단백질 함량 증가했다는 Erdman과 Sharma (1991)의 결과와는 차이를 보였다. 또한 본 시험에서 보호 choline의 급여가 무지고형 분, 총고형물, MUN 및 체세포수에 미치는 영 향이 적었던 결과는 보호 choline의 급여로 총 고형물은 증가하고 MUN은 감소되었다는 Piepenbrink와 Overton (2003)의 결과 및 보호 choline 의 급여가 체세포수에 미치는 영향은 없었다는 Erdman과 Sharma (1991)의 결과들과 부분적으 로 일치하거나 차이를 보여 보호 choline의 급 여가 이들 유성분 변화에 미치는 영향이 적거 나 일관성이 없는 것으로 판단된다.

보호 choline 급여시 몇몇 개별 지방산 함량 
이 유지방 함량의 높고 낮음에 따라 영향을 받 는 반면에 대부분의 지방산 함량에 대한 보호 choline의 영향은 적은 것으로 보고된 바 있다 (Piepenbrink와 Overton, 2003). 본 실험에서는 보호 choline의 급여로 유지방 함량이 증가되었 음에도 불구하고 모든 개별 지방산 함량이 통 계적인 유의차이를 보이지 않아 이전의 연구결 과와 일부 차이를 보였으나, 전반적인 지방산 에 대한 보호 choline의 영향은 없어 이전의 연 구결과와 대체적으로 유사한 경향을 보인 것으 로 생각되며 본 실험의 결과내에서 보호 choline의 급여가 우유의 지방산 조성에 미치는 영향은 적은 것으로 판단된다.

따라서 본 연구에서 반추위 보호 choline은 in vitro 반추위 발효에 대한 별다른 영향 없이 착유우의 산유량을 증가시키고 유지방 및 유당 함량을 효과적으로 증가시켜 착유우의 생산성 증진과 농가 소득증대에 활용 가치가 높은 것 으로 판단된다.

\section{IV. 요 약}

본 연구는 반추위 보호 choline의 급여가 in vitro 반추위 발효특성과 착유우의 유생산성에 미치는 영향을 검토하기 위해 수행되었다. 시 험구 배치는 기초사료 첨가구 (T1), 기초사료 $+23 \mathrm{~g} /$ 일 보호처리를 하지 않은 choline과 부형 제 첨가구 $(\mathrm{T} 2)$ 및 기초사료 $+25.56 \mathrm{~g} /$ 일 보호 choline 첨가구 (T3)의 3처리로 하였다. 보호 choline의 첨가가 in vitro 배양액의 $\mathrm{pH}$ 에 미치 는 영향은 3 시간을 제외한 전 배양시간에서 없 었으며, ammonia 농도에 대한 보호 choline의 영향도 배양 9 시간을 제외한 전 배양시간에서 없었다. 보호 choline의 첨가가 acetate 및 totalVFA 농도에 미치는 영향은 없었으며, propionate 및 butyrate 농도의 경우 배양 6시간을 제외한 전 배양시간에서 보호 choline 첨가의 영향도 없었다. 보호 choline의 급여로 착유우 의 산유량과 유지방 및 유당 함량이 증가되었
으나 $(\mathrm{p}<0.05)$, 보호 choline의 급여가 착유우의 유단백질, 무지고형분, 총고형물, MUN, 체세포 수 및 지방산에 미치는 영향은 없었다. 따라서 반추위 보호 choline은 in vitro 반추위 발효에 대한 별다른 영향 없이 산유량과 유지방 및 유 당 함량을 증가시키는데 효과적인 것으로 판단 된다.

\section{$\mathrm{V}$. 인 용 문 헌}

1. Atkins, K.B., R.A. Erdman and J.H. Vandersall. 1988. Dietary choline effects on milk yield and duodenal choline flow in dairy cattle. J. Dairy Sci. 71:109-116.

2. Auboiron S., D. Durand, J.C. Robert, M.J. Chapman and D. Bauchart. 1995. Effects of dietary fat and L-methionine on the hepatic metabolism of very low-density lipoproteins in the preruminant calf, Bos spp. Reprod. Nutr. Dev. 35:167-178.

3. Bell, A.W. 1995. Regulation of organic nutrient metabolism during transition from late pregnancy to early lactation. J. Anim. Sci. 73:2804-2819.

4. Bertics, S.J., R.R. Grummer and C. CadornigaValino. 1992. Effect of prepartum dry matter intake on liver triglyceride concentration and early lactation. J. Dairy Sci. 75:1914-1922.

5. Bindel, D.J., J.S. Drouillard, E.C. Titgemeyer, R. H. Wessels and C.A.L Est. 2000. Effects of ruminally protected choline and dietary fat on performance and blood metabolites of finishing heifers. J. Anim. Sci. 78:2497-2503.

6. Bryant, T.C., J.D. Rivera, M.L. Galyean, G.C. Duff, D.M. Hallford and T.H. Montgomery. 1999. Effects of dietary level of ruminally protected choline on performance and carcass characteristics of finishing beef steers and on growth and serum metabolites in lambs. J. Anim. Sci. 77:2893-2903.

7. Bygrave, F.L. and R.M.C. Dawson. 1976. Phosphatidylcholine biosynthesis and choline transport in the anaerobic protozoan Entodenium caudatum. Biochem. J. 160:481-490.

8. Cadorniga-Valino, C., R.R. Grummer, L.E. Armentano, S.S. Donkin and S.J. Bertics. 1997. Effects of 
fatty acids and hormones on fatty acid metabolism and gluconeogenesis in bovine hepatocytes. J. Dairy Sci. 80:646-656.

9. Durand, D., Y. Chilliard and D. Bauchart. 1992. Effects of lysine and methionine on in vivo hepatic secretion of VLDL in the high yielding dairy cow. J. Dairy Sci. 75(Suppl. 1) 279.(Abstr.)

10. Emery, R.S., J.S. Liesman and T.H. Herdt. 1992. Metabolism of long-chain fatty acids by ruminant liver. J. Nutr. 122:832-837.

11. Emmanuel, B. and J.J. Kennelly. 1984. Kinetics of methionine and choline and their incorporation into plasma lipids and milk components in lactating goats. J. Dairy Sci. 67:1912-1918.

12. Erdman, R.A. 1984. Choline: Functions and Requirements. DUCOA, Highland, IL.

13 Erdman, R.A. 1992. Vitamins. pp. 297-308 In Large Dairy Herd Management. H.H. Van Horn and C.J. Wilcox, Ed. Am. Dairy Sci. Assoc., Champaign, IL.

14. Erdman, R.A. and B.K. Sharma. 1991. Effect of dietary rumen-protected choline in lactating dairy cows. J. Dairy Sci. 74:1641-1647.

15. Folch, J., M. Lees and G.H.S. Stanley. 1957. A simple method for the isolation and purification of total lipid from animal tissues. J. Biol. Chem. 226:497-509.

16. Grummer, R.R. 1993. Etiology of lipid-related metabolic disorder in periparturient dairy cows. J. Dairy Sci. 76:3882-3896.

17. Hartwell, J.R., M.J. Cecava and S.S. Donkin. 2000. Impact of dietary rumen undegradable protein and rumen protected choline on intake, peripartum liver triglyceride, plasma metabolites and milk production in transition dairy cattle. J. Dairy Sci. 83:2907-2917.

18. Kerri, N.D., L.S. Piperova and R.A. Erdman. 1998. Milk choline secretion as an indirect indicator of postruminal choline supply. J. Dairy Sci. 81:238-242.

19. McDowell, L.R. 1989. Vitamins in animal nutrition. Academic press. 347-364.

20. Neil, A.R., D.W. Grime and R.M.C. Dawson. 1978. Conversion of choline methyl groups through trimethyl amine into methane in the rumen. Biochemical J. 170:529-535.
21. NRC. 2000. Nutrient Requirements of Beef Cattle. National Academy Press, Washington, DC.

22. NRC. 2001. Nutrient Requirements of Dairy Cattle. National Academy Press, Washington, DC.

23. Piepenbrink, M.S. and T.R. Overton. 2003. Liver metabolism and production of cows fed increasing amounts of rumen-protected choline during the periparturient period. J. Dairy Sci. 86:1722-1733.

24. Pinotti, L., A. Baldi, G. Savoini and V. Dell Orto. 2001. Effects of rumen protected choline on lipid metabolism in periparturient high yielding dairy cows. Livest. Prod. Sci. 70:176.(Abstr.)

25. Reid, I.M. and R.A. Collins. 1980. The pathology of post-parturient fatty liver in high-yielding dairy cows. Invest. Cell Pathol. 3:237-249.

26. SAS. 1999. SAS/STAT Software for PC. Release 6.11, SAS Institute, Cary, NC, U.S.A.

27. Sharma, B.K. and R.A. Erdman. 1987. Effect of abomasal infusion of choline on milk production responses of lactating dairy cows. J. Dairy Sci. 70(Suppl. 1):215. (Abstr.)

28. Sharma, B.K. and R.A. Erdman. 1988. Effect of high levels of dietary choline supplementation on duodenal choline flow and production responses of dairy cows. J. Dairy Sci. 71:2670-2676.

29. Sharma, B.K. and R.A. Erdman. 1989. Effects of dietary and abomasally infused choline on milk production responses of lactating dairy cows. J. Nutr. 119:248-254.

30. Sukhija, P.S. and D.L. Palmquist. 1988. Rapid method for determination of total fatty acid content and composition of feedstuffs and feces. J. Agric. Food Chem. 36:1202-1206.

31. Swingle, R.S. and I.A. Dyer. 1970. Effects of choline on rumen microbial metabolism. J. Anim. Sci. 31:404-408.

32. Van Horn. H.H. and C.J. Wilcox. 1999. Large Dairy Herd Management. American Dairy Science Association. pp. 306-307.

(접수일: 2008년 5월 15일, 수정일 1차: 2008년 5월 30일, 수정일 2차 7월 11일, 게재확정일: 2008년 7월 17일) 